\title{
Evidence of Young Humpback Chub Overwintering in the Mainstem Colorado River, Marble Canyon, Arizona, USA
}

\author{
Matthew E. Andersen ${ }^{1, *}$, Michael W. Ackerman ${ }^{2}$ and Kara D. Hilwig ${ }^{1}$, A. Elizabeth Fuller ${ }^{1}$ and Paul \\ D. Alley ${ }^{1}$ \\ ${ }^{1}$ U.S. Geological Survey, Grand Canyon Monitoring and Research Center, Flagstaff, AZ 86001 USA \\ ${ }^{2}$ SWCA Environmental Consultants, Inc., Flagstaff, AZ USA 86001
}

\begin{abstract}
Global climate change models predict that the southwestern United States will become warmer and drier, resulting in decreased reservoir volumes, increased water temperatures, and changes in fish distributions. Such conditions may also result from drought and water extraction. Our observations of humpback chub Gila cypha allowed us to test predicted impacts of increased water temperatures released from Glen Canyon Dam on this federally listed endangered cyprinid endemic to the Colorado River Basin. We modeled the potential that the young humpback chub we captured in 2006 and 2007 were hatched and reared up to $50 \mathrm{~km}$ upstream from the Little Colorado River, the natal origin of the majority of the humpback chub population below Glen Canyon Dam. Larval and adult humpback chub have been observed by others in our study reach in the post-dam era. Humpback chub assumed to be juveniles have been observed in our study area, but their ages were not confirmed. Our observations of humpback chub were coincident with not only increased water temperatures as a result of regional drought, but also decreasing rainbow trout population numbers and some constraints on dam release fluctuations. One or all of these factors could have contributed to increased survivorship of young humpback chub. The most parsimonious explanation for our observations was that the largest young humpback chub captured at our study site took advantage of warmer water temperatures to grow to one and two years of age. Continued favorable habitat conditions in this reach would likely support recruitment to adulthood and reproduction. Managers wish to increase the likelihood that a self-sustaining mainstem Colorado River population of humpback chub is established, distinct from the larger Little Colorado River population. Our results indicate that a separate population may be successfully established.
\end{abstract}

Key Words: Colorado River, Grand Canyon, humpback chub, endangered species, bioenergetics, modeling to inform management.

\section{INTRODUCTION}

Recent analyses of global climate change and water use patterns predicts loss of fish species around the world in the coming century, including in the Colorado River of the southwest United States [1-2]. Analyses of the patterns of these changes predict that warm water fishes [3-6], including cyprinids [7-8] and, in some cases, nonnative fishes [9] will expand their distributions in response to global climate change patterns, while cool and cold water fishes will be more likely to experience declines. Drought in the Colorado River Basin, regardless of the cause, and/or increased water withdrawals upstream will also cause reduced flows and reservoir levels in Lake Powell leading to warmer release water temperatures from Glen Canyon Dam. The humpback chub Gila cypha, a warm water cyprinid endemic to the Colorado River in Grand Canyon, including Marble Canyon, offers an opportunity to examine a local response to changes in reservoir condition. The humpback chub population of Grand Canyon is distributed in both Marble Canyon, upstream from the mouth of the Little Colorado River, and in Grand Canyon

*Address correspondence to these authors at the U.S. Geological Survey, Grand Canyon Monitoring and Research Center, Flagstaff, AZ 86001 USA; Tel: (928) 556-7379; Fax: (928) 556-7092; E-mail: mandersen@usgs.gov proper, downstream from the Little Colorado River. Marble and Grand Canyons together are collectively referred to as Grand Canyon in this article (Fig. 1). The local standard for referring to Colorado River locations in Glen, Marble, and Grand Canyons is by longitudinal River Miles above or below Lees Ferry, a convention we follow.

The humpback chub population in Grand Canyon has been exposed to cooler water temperatures, particularly in the summer and fall months, in the years since the Glen Canyon Dam on the Colorado River was closed in 1963 to provide water storage and delivery and also for hydropower generation. Cooler water temperatures were hypothesized to have led to the population decline observed by Douglas and Marsh [10] an effect supported by the work of Clarkson and Childs [11]. However, beginning in 2000, reduced precipitation and warmer temperatures in the Colorado River Basin upstream of Glen Canyon Dam resulted in a decreasing surface elevation on Lake Powell, the reservoir impounded by Glen Canyon Dam, causing it to drop to levels not seen since the dam was first closed and the reservoir began its initial filling [12]. Water temperatures released from Glen Canyon Dam from 2003 through 2006 were above the 12-year running average, reaching a high of $16^{\circ} \mathrm{C}$ in October 2006 [13]. Released water temperatures were slightly lower in 2007 than in 2006 (Fig. 2). Release fluctuations to generate hy- 


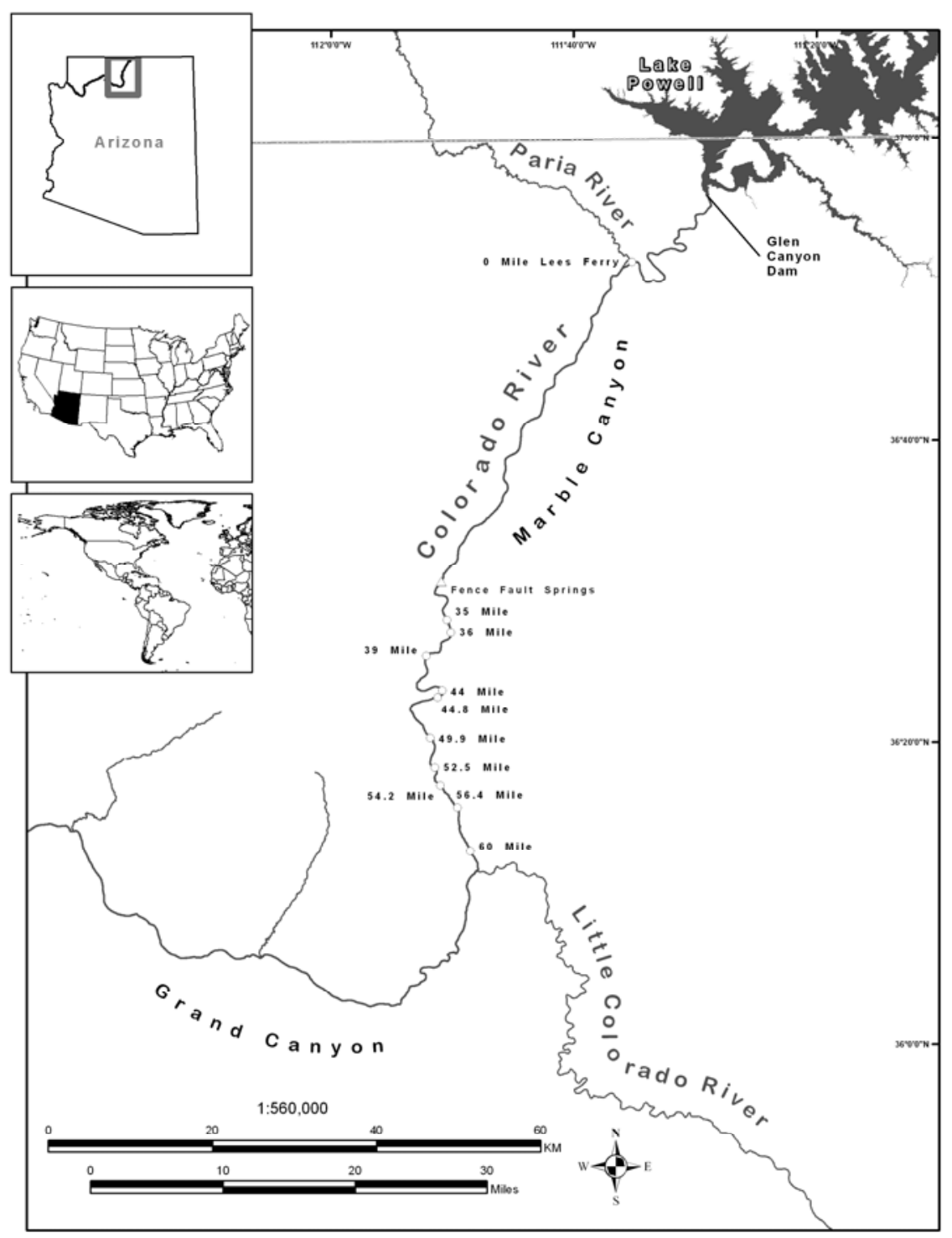

Fig. (1). Map of Colorado River in Marble Canyon from Lake Powell and Glen Canyon Dam to the mouth of the Little Colorado River where Grand Canyon proper begins. Areas of high flow referred to in the text are indicated by their river mile number.

dropower were moderately constrained in 2006 and 2007 compared to previous years. Water released from Glen Canyon Dam warms as it goes downstream, especially between June and September, when solar radiation is high in this reach of the river that runs generally from north to south [14].

There are eight known springs emerging near Fence Fault, River Miles 30-34.5 [15] that release their water into the Colorado River to provide additional, local warming. Spring temperatures range from $17^{\circ} \mathrm{C}$ to $22^{\circ} \mathrm{C}$. Depending on the season and the year, these temperatures may be substantially warmer than the mainstem Colorado River in this reach that, in the post-dam era, varies between $9^{\circ} \mathrm{C}$ and $16^{\circ} \mathrm{C}$ [13]. Mainstem river temperatures in the immediate vicinity of the springs have been measured at $11^{\circ} \mathrm{C}$ to $21^{\circ} \mathrm{C}$ [15]. The results of our examination of observed captures compared to growth model results suggests that climate warming in the Colorado River basin may have had an indirect impact on the humpback chub population by expanding suitable nursery habitat (warmer water) beginning at River Mile 30, $75 \mathrm{~km}$ below Glen Canyon Dam, and extending downstream.

Humpback chub is a federally listed endangered species currently found in six discrete populations in the Colorado River Basin of western North America [16]. The southernmost of these populations is found in the Little Colorado and Colorado Rivers in Grand Canyon, which includes those individuals found in Marble Canyon. Individual humpback chub may reach $480 \mathrm{~mm}$ and more than $1 \mathrm{~kg}$ during their 30 or more years of life $[17,18]$. They reach sexual maturity in the wild in about four years [17-19], though rate of maturation is highly dependent on water temperature [18]. The Grand Canyon adult population experienced a decrease of more than 50\% between 1989 and 2001, but increased about $50 \%$ between 2001 and 2008, and currently numbers approximately 7,650 adult fish four years old or older [20]. Despite recent adult population increases, managers remain concerned about the long-term fate of the Grand Canyon humpback chub population in part because most or all of the 


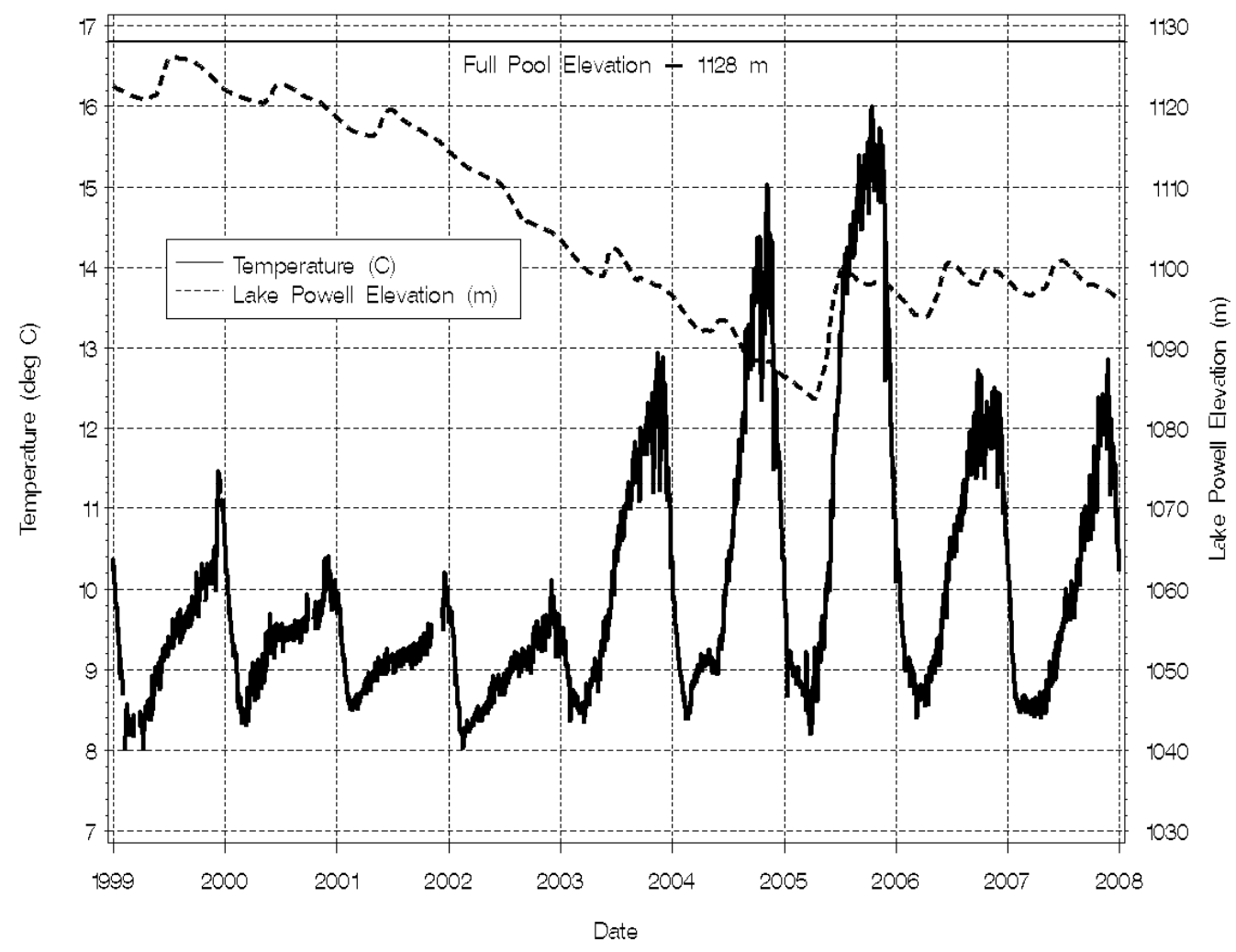

Fig. (2). Comparison of Lake Powell surface elevations and Glen Canyon Dam release temperatures 1999-2007.

reproduction occurs in one tributary, the Little Colorado River [10, 21, 22]. The Little Colorado River provides a warmer, relatively constant aquatic environment [13] in which humpback chub can reproduce and mature, though this environment is disrupted regularly by seasonal storm events.

The majority of the Grand Canyon humpback chub population, including in the Colorado and Little Colorado Rivers, spawn between March and May [19, 22, 23]. At $20^{\circ} \mathrm{C}$, the approximate mean temperature of the Little Colorado River [13], fertilized eggs incubate for about three days before hatching [24]. Growth and maturation is faster in the Little Colorado River [25], than in the mainstem Colorado River $[11,17,18]$. For example, Minckley [25] reported humpback chub in the Little Colorado River grew at $10 \mathrm{~mm} / 30$ days, while Valdez and Ryel [17] reported humpback chub in the mainstem Colorado River grew at 2-4 mm/30 days. Coggins [18] used mark-recapture data to confirm that humpback chub growth rates are faster in the Little Colorado River than in the mainstem Colorado River.

There are nine known aggregations of humpback chub found repeatedly in Grand Canyon [17, 26]. Proceeding downstream from Glen Canyon Dam and Lees Ferry, the first is found in our study reach, 30 Mile, river miles (RM) 29.8-31.3, approximately $50 \mathrm{~km}$ below Lees Ferry (Fig. 1). The second is in the vicinity of the Little Colorado River Inflow, RM 57-65.4, between 95 and $109 \mathrm{~km}$ downstream of Lees Ferry. The remaining seven aggregations are all below the Little Colorado River inflow. The reach of the Colorado River that includes the mouth of the Little Colorado River is the only mainstem aggregation where successful recruitment of humpback chub to the adult size class has been repeatedly documented [17, 18, 22, 23]. The humpback chub captured in aggregations downstream of the Little Colorado River may have been produced locally (the humpback chub in these aggregations exhibit high site fidelity [26]) or may have been produced in the Little Colorado River and drifted downstream. The 30 Mile aggregation is unique because it is the only Grand Canyon aggregation upstream of the Little Colorado River. Valdez and Masslich [27] documented postlarval $(\mathrm{n}=14$, mean total length $=24 \mathrm{~mm}$, range $=18-31$ $\mathrm{mm}$ ) and adult humpback chub in the 30 Mile reach. Valdez and Masslich [27] also reported that juvenile humpback chub (32-300 $\mathrm{mm}$ ) had been observed by multiple personnel in Marble Canyon but could not confirm the ages of these fish. Movement of some adult humpback chub from the Little Colorado River upstream to 30 Mile has been documented [26].

Nonnative fishes are known to threaten native fishes in the Colorado River Basin [28, 29]. Representatives of various cyprinid, salmonid, ictalurid, and centrarchid species competitors and predators are known from the mainstem Colorado River between Lees Ferry and the Little Colorado River [30, 31]. Rainbow trout Oncorhynchus mykiss has been the nonnative species with the largest population in this river reach in recent times is [17, 31, 32]. Because of the threat to humpback chub posed by rainbow trout and other nonnative species, the Glen Canyon Dam Adaptive Management Program mounted a removal program for nonnative fishes, employing night time boat-mounted electroshocking, that removed more than 19,000 rainbow trout between 2003 and 2006 in the reach between River Miles 55 to 75, downstream of the 30 Mile aggregation [31]. Rainbow trout numbers were decreasing throughout the system during this time 
period, likely in response to over-population in River Miles 15 to 0 leading to density-dependent population reductions (sensu [33]). The warming releases from Glen Canyon Dam during the period 2002-2007 in river miles -15 to 0 (Glen Canyon Dam to Lees Ferry) increased into the temperature range in which rainbow trout grow optimally and prefer [34, 35 ], so water temperature does not appear to have been limiting.

Suspended sediment below Lees Ferry in Marble Canyon was elevated over levels observed in the 1990s beginning in 2004 [36]. Because high levels of suspended sediment can have negative impacts on salmonids, including rainbow trout [37], the elevated suspended sediment in the Colorado River during our study may have negatively impacted the resident rainbow trout population. Numbers of rainbow trout in River Miles -15 to 75 were relatively low between 2000 and 2007 when compared to the 1990s. It appears that density dependent decreases, mechanical removal, and increased sediment may have all contributed to the observed decrease in the rainbow trout population.

Both runs and high velocity areas (riffles, runs, and rapids) are found on the Colorado River between River Miles 30 and 56 in Marble Canyon (Fig. 1). Of the 100 or more rapids in greater Grand Canyon, including Marble Canyon [38], the rapids in Marble Canyon are the least severe owing to a relatively more gradual drop in this portion of the Canyon, the "eastern convexity" of Hanks and Webb [39]. Owing to substantial logistical and technical constraints, the actual velocity of water through all Grand Canyon rapids has not been determined. Magirl [38] was able to determine instantaneous velocities in two Colorado River rapids at a single release volume, but releases are variable and it is known that velocities vary across the width of the stream in the boulder-strewn rapids of the Colorado River. While maximum velocities at typical post-dam release levels in the heart of rapids may be greater than $5 \mathrm{~m} / \mathrm{s}$, velocities in the boulder-laden margins and near the bottom of channels in Grand Canyon may be less than $0.5 \mathrm{~m} / \mathrm{s}$ [38]. In general, flows in high velocity riffles and rapids are most often higher than in the intervening runs, and so present fish swimming upstream with obstacles requiring greater expenditure of energy [39] than the intervening runs.

Between rapids and runs, lower velocity backwaters form in the Colorado River in Marble and Grand Canyons, usually as a result of return current eddies that deposit sand bars downstream of large debris fans $[40,41]$. These sand bars isolate the shallow backwaters from the mainstem where water may warm when exposed to sunlight, especially in the late summer and early fall months. During our sampling in 2006 we observed water temperatures in backwaters that were warmer than the mainstem, especially later in the day when the backwaters had been exposed to solar radiation. Our sampling in 2007 was conducted on days when cloud cover was present, limiting solar radiation, and so the backwaters did not warm appreciably above the mainstem river temperatures during collection days in that year.

\section{METHODS}

We surveyed backwater habitats in Marble and Grand Canyons in the fall of each year 2002 through 2007. The sampling teams seined backwater habitats with seines measuring $3.65 \mathrm{~m} \times 1.82 \mathrm{~m} \times 3.18 \mathrm{~mm}$ (width $\mathrm{x}$ depth $\times$ mesh). Fish were sampled in the 30 Mile reach in this fashion 200207.

Each backwater was seined starting at the opening to the mainstem and ending at the terminus. In backwaters in which the mouth was too deep to safely sample, the haul was started where personnel could safely cross the backwater with one end of the seine. All of the fish caught in the seine were transferred into a bucket. Each fish was identified by species and measured for total length. After data were collected, all fish were released back into the backwater. Water temperatures were recorded in each backwater habitat sampled. Water temperatures in the adjacent mainstem river were also recorded.

We used the bioenergetics parameters developed by Petersen and Paukert [32] for young humpback chub in Fish Bioenergetics 3.0 [42]. Fish Bioenergetics 3.0 utilizes the general bioenergetics equation

$$
\mathrm{G}=\mathrm{C}-(\mathrm{R}+\mathrm{SDA}+\mathrm{F}+\mathrm{E})
$$

where $\mathrm{G}$ is growth, $\mathrm{C}$ is consumption, $\mathrm{R}$ is respiration, $\mathrm{SDA}$ is specific dynamic action, $\mathrm{F}$ is excretion, and $\mathrm{E}$ is egestion. The basic form of the consumption function is

$$
\begin{aligned}
& \mathrm{C}=\mathrm{C}_{\max } \times p \times f(\mathrm{~T}), \text { where } \\
& \mathrm{C}_{\max }=\mathrm{CA} \times \mathrm{W}^{\mathrm{CB}},
\end{aligned}
$$

where $\mathrm{C}$ is specific consumption rate, $\mathrm{C}_{\max }$ is maximum specific feeding rate, $p$ is proportion of maximum consumption, $f(T)$ is a temperature dependence function, $T$ is water temperature, $\mathrm{W}$ is fish mass, $\mathrm{CA}$ is intercept of the allometric mass function, and $\mathrm{CB}$ is slope of the allometric mass function. The basic form of the respiration and specific dynamic action functions are

$$
\begin{aligned}
& \mathrm{R}=\mathrm{RA} \times \mathrm{W}^{\mathrm{RB}} \times f(\mathrm{~T}) \times \mathrm{ACT}, \\
& \mathrm{S}=\mathrm{SDA} \times(\mathrm{C}-\mathrm{F}),
\end{aligned}
$$

where $\mathrm{R}$ is specific rate of respiration, $\mathrm{W}$ is fish mass, $\mathrm{RA}$ is intercept of the allometric mass function, $\mathrm{RB}$ is slope of the allometric mass function, $f(T)$ is temperature dependence function, $\mathrm{T}$ is water temperature, ACT is activity multiplier, $\mathrm{S}$ is proportion of assimilated energy lost to specific dynamic action, SDA is specific dynamic action, $\mathrm{C}$ is specific consumption rate, and $\mathrm{F}$ is specific egestion rate. For additional detail see [42].

Petersen and Paukert [32] used the warmwater form for the temperature dependence of both consumption and respiration [43] and we did also. Petersen and Paukert [32] estimated bioenergetic parameter values for young humpback chub by Monte Carlo filtering and corroborating modeled humpback chub growth with growth rates from independent field and laboratory studies.

As a result of the high amount of variance associated with CA, CB, RA, RB, and ACT, equations (3) and (4), a sensitivity analysis was conducted on each of these parameters to see how altering each of these values influenced 
growth of young of the year humpback chub. Both birth date and temperature were kept constant. Each of the individual parameters (CA, CB, RA, RB, and ACT) was altered over a range of values while keeping all other parameters constant (Table 1). After establishing which of the parameter values allowed for optimal growth of young of year humpback chub, that value was evaluated over a range of proportions of maximum consumption $(p)$. Petersen and Paukert [32] showed that a $p$-value near 0.6 likely approximates the actual $p$-value humpback chub experience in the wild. In addition, certain combinations of the optimum values were evaluated, including CA-CB, RA-RB, RA-RB-ACT, and RA-RB-ACTCA-CB.

We used the bionenergetics model to determine what mass a young humpback chub could achieve by the capture date in their first year of life. For model runs, April $1^{\text {st }}$ was used as the birth date. April $1^{\text {st }}$ is a conservatively early estimate for birth date and is likely earlier (and would allow for more growth) than the typical birth date for humpback chub observed in the Little Colorado River of March to May [22, 23, 44, 45]. Growth simulations were always run until the last capture date of each year's sampling; September $25^{\text {th }}$ in 2006 and September $22^{\text {nd }}$ in 2007 . Because of the variety of factors that determine the actual water temperatures that an individual young of year humpback chub experiences in their first year, simulations were run using the average daily temperature of the mainstem Colorado River recorded at River Mile 30. As noted above, backwater habitats usually warm when exposed to sunlight, so using the mainstem temperature is likely a conservative (cooler) estimate of the temperature to which our specimens were exposed on sunny days.

Output of the Fish Bioenergetics 3.0 is always given as mass (g). In order to compare the length of simulated fish with fish captured in the 30 Mile reach, the output of each simulation had to be converted to length using a lengthweight relationship. We developed the length-weight regression equation from weight measurements $(\mathrm{g})$ of humpback chub ranging from $55-150 \mathrm{~mm}$ total length captured in the Colorado and Little Colorado Rivers in Grand Canyon from 1981 through 2001. The equation derived is:

$$
\ln (\text { Total Length })=0.316(\ln (\text { Weight }))+3.937
$$

We used this equation to predict the length of a humpback chub based on model outputs of weight and calculated the prediction intervals $(\mathrm{p}=0.05)$.

\section{RESULTS}

Subadult humpback chub were captured in backwaters in the 30 Mile reach in 2006 in water temperatures that ranged between $12^{\circ} \mathrm{C}$ and $21.7^{\circ} \mathrm{C}$. In previous years the length distributions of the subadult humpback chub captured were not suggestive of two or more distinct age classes, as in 2005 (Fig. 3). The largest humpback chub captured in this reach in 2005 was $59 \mathrm{~mm}$.

The length distribution for humpback chub captured in the 30 Mile reach in 2006 (Fig. 4) and 2007 (Fig. 5) differed from 2005 in that there were distinct distributional patterns to the data, especially for the 2006 data. The largest humpback chub captured in this reach in 2006 was $66 \mathrm{~mm}$, and 80 $\mathrm{mm}$ in 2007.

Mainstem water temperatures for the period of this report in our study reach are nearly identical to the released water temperatures shown in Fig. (2) [13]. Water temperatures in backwaters exhibit a diurnal pattern, warming with sunlight and cooling off at night, on sunny days. Subadult humpback chub were captured in backwaters in the 30 Mile reach in 2006 in water temperatures that ranged between $12^{\circ} \mathrm{C}$ and $21.7^{\circ} \mathrm{C}$ depending on time of capture. The backwater with $21.7^{\circ} \mathrm{C}$ water was located at River Mile 31. Backwaters were fewer, and backwater temperatures were cooler, in 2007, ranging from 11.8 to $13.3^{\circ} \mathrm{C}$ owing to overcast skies and cooler ambient air temperatures.

Simulations from Fish Bioenergetics 3.0 show that under mean daily temperatures at River Mile 30, and given a very conservative (early) birth date of April $1^{\text {st }}$, a young of year humpback chub would have grown to $27 \mathrm{~mm}$ (upper 95\% PI $=31 \mathrm{~mm}$ ) in 2006 and $26 \mathrm{~mm}$ (upper 95\% PI = $29 \mathrm{~mm}$ ) in 2007 by their capture date at a $p$-value of 0.6 using the parameters determined with Monte Carlo filtering by Petersen and Paukert [32]. When all parameters analyzed (CA, CB, $\mathrm{RA}, \mathrm{RB}$, and ACT) were set for optimum growth, simulated fish achieved mass corresponding to a length of $48 \mathrm{~mm}$ (upper $95 \% \mathrm{PI}=54 \mathrm{~mm}$ ) in 2006 and $45 \mathrm{~mm}$ (upper $95 \% \mathrm{PI}=$

Table 1. Parameters for Which a Sensitivity Analysis was Conducted. Parameter Values Shown with an Asterisk (*) are Values Tested that are Optimum for Growth of Young Humpback Chub

\begin{tabular}{|c|c|c|c|c|c|c|c|c|}
\hline \multirow{2}{*}{ Parameter } & \multicolumn{3}{|c|}{ Petersen and Paukert (2005) } & \multicolumn{5}{|c|}{ Sensitivity Analysis } \\
\hline & Range Min & Monte Carlo & Range Max & Low & & Monte Carlo & & High \\
\hline \multicolumn{9}{|c|}{ Consumption } \\
\hline CA & 0.11 & 0.154 & 0.2 & 0.114 & 0.134 & 0.154 & 0.174 & $0.194 *$ \\
\hline $\mathrm{CB}$ & -0.3 & -0.251 & -0.2 & $-0.291 *$ & -0.271 & -0.251 & -0.231 & -0.211 \\
\hline \multicolumn{9}{|c|}{ Respiration } \\
\hline RA & 0.0004 & 0.0049 & 0.01 & $0.0009 *$ & 0.0029 & 0.0049 & 0.0069 & 0.0089 \\
\hline $\mathrm{RB}$ & -0.15 & -0.084 & -0.02 & -0.134 & -0.109 & -0.084 & -0.059 & $-0.034^{*}$ \\
\hline ACT & 0.5 & 1.16 & 2.0 & $0.56^{*}$ & 0.86 & 1.16 & 1.46 & 1.76 \\
\hline
\end{tabular}




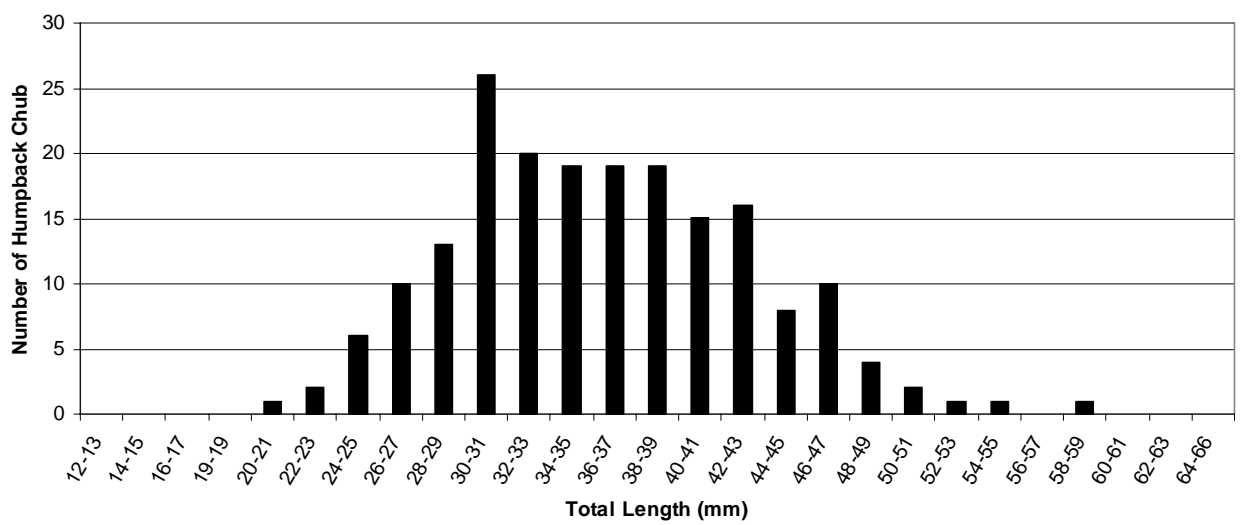

Fig. (3). Length frequency distribution of humpback chub captured by seining in the Colorado River in Marble Canyon between River Miles 30 and 56.5 in September 2005.

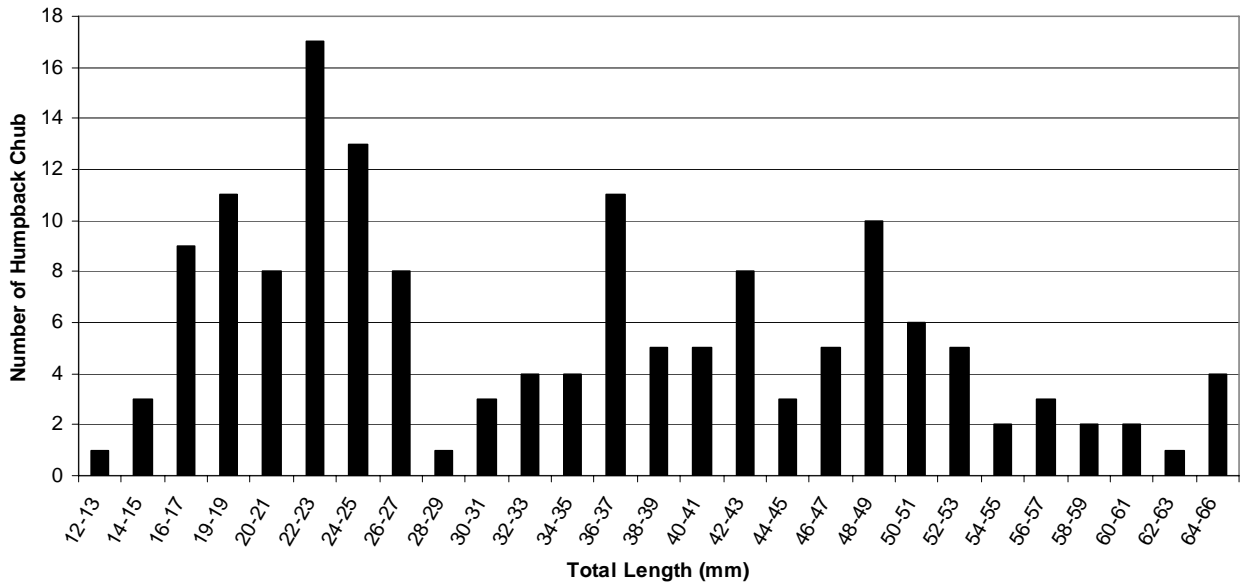

Fig. (4). Length frequency distribution of humpback chub captured by seining in the Colorado River in Marble Canyon between River Miles 30 and 56.5 in September 2006.

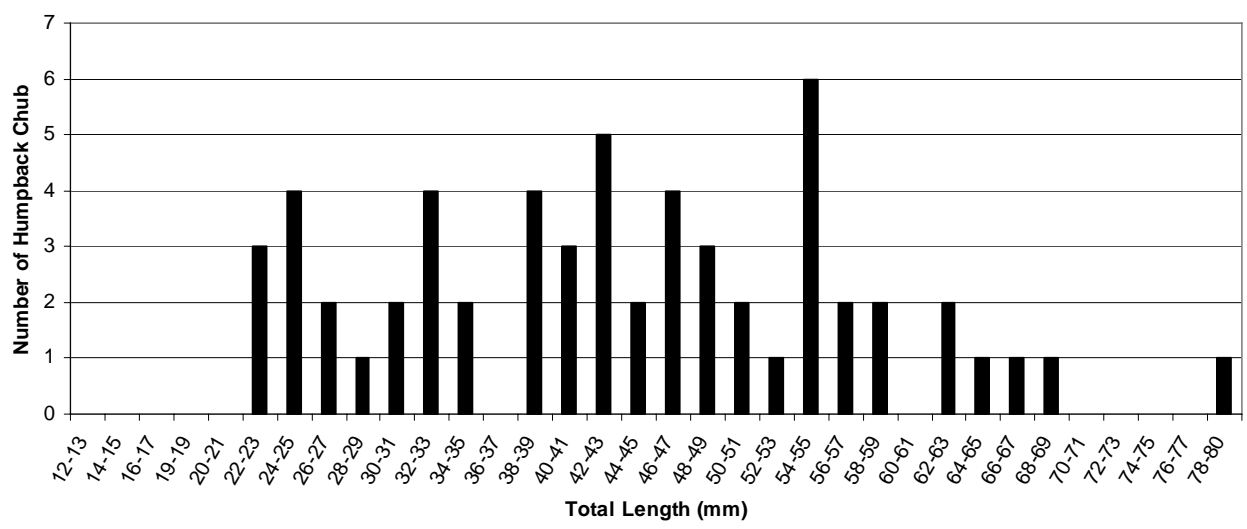

Fig. (5). Length frequency distribution of humpback chub captured by seining in the Colorado River in Marble Canyon between River Miles 30 and 56.5 in September 2007.

$51 \mathrm{~mm}$ ) in 2007 at a p-value of 0.6 . In 2006 we captured 154 humpback chub, of which 35 (23\%) were $48 \mathrm{~mm}$ or larger. In 2007 we captured 58 humpback chub of which $26(45 \%)$ were $45 \mathrm{~mm}$ or larger. In 2006 our captures were on 22, 24, and 25 September. From 1 April to 22 September is 175 days. A fish that achieved $48 \mathrm{~mm}$ length in 175 days grew at a mean rate of $0.27 \mathrm{~mm} /$ day. In 2007 our captures were on 21 and 22 September. From 1 April to 21 September is 174 days. A fish that achieved $45 \mathrm{~mm}$ in 174 days grew at a mean rate of $0.26 \mathrm{~mm} / \mathrm{day}$. 
These growth rates are near the high summer, short-term estimate of Minckley [25]. When we allow for an additional year to grow to the modeled minimum size of $48 \mathrm{~mm}$ and 45 $\mathrm{mm}$ long for fish captured in 2006 and 2007, respectively, the growth rates are $0.089 \mathrm{~mm} /$ day for 2006 and 0.083 for 2007 , values similar to the approximately $0.1 \mathrm{~mm} /$ day rate reported by Valdez and Ryel [17].

\section{DISCUSSION}

The evidence presented in this article strongly suggests that a proportion of young of year humpback chub produced in the 30 Mile reach of the Colorado River in Marble Canyon, upstream of the main Grand Canyon, overwintered to reach age 1 in both 2006 and 2007. Furthermore, a small proportion of the fish produced in 2005 may have survived over the winters of 2005-06 and 2006-07 to reach age 2. It is likely that we captured at least 35 age- 1 humpback chub (from the 2005 year class) in 2006 and at least 26 age-1 humpback chub (from the 2006 year class) in 2007. Using empirical water temperatures and the modeling refined by Petersen and Paukert [32] we determined that the largest captured humpback chub in 2006 and 2007 were much more likely to have been produced in the previous year; growth to the largest sizes in five or six months is highly unlikely.

Despite the strong evidence of our post-hoc analysis for overwintering and additional humpback chub growth in Marble Canyon, there are other possible explanations for our observations. We cannot categorically dismiss the potential that young humpback chub will swim upstream in the Colorado River from the mouth of the Little Colorado River, the natal origin for most Grand Canyon humpback chub. While there are at least 9 rapids, or other high velocity areas, in the mainstem between River Miles 30 and 56.3, these areas have been shown to be highly variable, with areas of low flow, 1 $\mathrm{m} / \mathrm{s}$ or less, found along the margins of the river $[38,46]$. We do not hypothesize that one-year-old and younger humpback chub would leave an area of moderate currents and sufficient food, such as the Little Colorado River, to expend energy to swim upstream, but the literature suggests that such swimming could be possible.

Berry and Pimentel [47] determined that the 120 minute absolute swimming speed at $14^{\circ} \mathrm{C}$ for humpback chub was $0.40 \mathrm{~m} / \mathrm{s}$, so fish swimming upstream are likely to have needed to expend additional energy to locate areas of lower velocity if they chose to leave the Little Colorado River reach or they employed high-energy, short-duration, critical maximum swimming speeds to move upstream [48]. The results of Berry and Pimentel [47] are generally consistent with the results of Ward [49] for a closely related species, bonytail Gila elegans, and to other cyprinids [50]. In general, fish swim more slowly at cooler-than-optimum temperatures [50] owing to a faster conversion to less efficient anaerobic metabolism at cooler temperatures [51]; the water temperatures we observed were cooler than those tested by Berry and Pimentel [47] for much, but not all, of the year. Cyprinids are generally strong swimmers, and can employ physiologic mechanisms to maintain their position in strong currents, including grasping surfaces with their mouths when critical swimming speeds are exceeded [52]. Oral grasping has not been observed in humpback chub (nor in any cyprinids in the wild), but such adaptations illustrate how the cyprinid humpback chub may have evolved strategies and adaptations that allow it to move against strong flows when required. Because high flows that overtop rapids will reduce the velocities in these locations, such flows could be invoked to explain fish movement above rapids, but such high flows did not occur during the period when our study fish were collected.

Swimming upstream would be very energetically expensive, and unlikely when considering that food resources are available below these rapids. Although we cannot identify the natal origin of the young humpback chub we captured in the 30 Mile reach with absolute certainty, it is most parsimonious, and even conservative, to conclude that the humpback chub greater than $48 \mathrm{~mm}, \mathrm{n}=35$, that were captured in the 30 Mile reach in September 2006 were produced in this reach in the hatch of 2005 , and that humpback chub greater than $46 \mathrm{~mm}, \mathrm{n}=26$, captured in this reach in 2007 were produced in 2006.

Our data do not allow us to draw definitive conclusions in this report regarding the reasons for overwinter survival of humpback chub. However, we note that during the winters of 2005-06 and 2006-07, there were three conditions that we would hypothesize were consistent with increased survival of this species in the mainstem Colorado River. First, water temperatures were warmer than they had been for many years following the closure of Glen Canyon Dam. Secondly, the rainbow trout population was lower than it had been since the mid-1990s. Thirdly, we note that the release fluctuations were constrained in 2006 and 2007 compared to 2005. One or all of these factors may have contributed to increased overwinter survival. Our results and the three correlated conditions described above suggest that if resource managers wish to establish a second population of humpback chub based in the mainstem Colorado River in Grand Canyon then such conditions may be required. Further experimentation with nonnative fish control, water temperatures, and flow conditions could be utilized to help resolve the causative factors, which in turn would provide more definitive parameters to support management decisions.

The humpback chub population in Grand Canyon is almost entirely dependent on the Little Colorado River for reproduction and survival of young. While this tributary has been supporting an increasing population since 2001 [20], the dependency on a single tributary presents inherent risks to this, or any other, wild fish population because one catastrophic event, such as an anthropogenic accident or widespread disease, could decimate such a concentration of the species. If conditions in the mainstem Colorado River can be modified to encourage more widespread reproduction and survival the single-tributary risk to the population can be reduced. The results of our study suggest that if predatory/competitive fish can be reduced and warmer water and steadier flows are available, then humpback chub can find conditions that will allow them to overwinter in the mainstem Colorado River in Marble and Grand Canyons. Natural resource managers have expressed interest in determining whether mainstem populations of humpback chub can be supported through survival that allows for recruitment into the adult population and reproduction. The analysis we con- 
ducted suggests that suitable mainstem conditions may allow humpback chub to persist in mainstem habitats.

The change we observed in the Grand Canyon humpback chub population distribution, albeit small, was consistent with models predicting cyprinid expansions during times of warmer atmospheric temperatures and reduced river discharge. At least at this localized scale the effects of climate change (less precipitation, higher air temperatures) appear to have encouraged expanded distribution of humpback chub in the mainstem Colorado. Our data show that backwater habitats may provide temporary thermal refuges, although these habitats are not consistently warmer than the mainstem and they cool diurnally when not exposed to direct sunlight.

Continued warm, dry conditions are forecast for the southwestern United States [53]. It remains to be seen whether these effects will continue to support expanded distribution of humpback chub in Grand Canyon. Warm, dry meteorological conditions led to a lower Lake Powell elevation and warmer releases from Glen Canyon Dam into the Colorado River below the dam. While such releases benefit humpback chub, they also have high potential to benefit nonnative warm water fishes [6] already present in Grand Canyon, such as common carp Cyprinus carpio, fathead minnow Pimephales promelas, and channel catfish Ictalurus punctatus. While increasing water temperatures are favorable to the fishes that evolved in Grand Canyon, and so should be provided by managers wishing to conserve humpback chub to the extent possible, such actions will have to include aggressive control of nonnative, warm water fishes if the natives are to thrive in the altered aquatic environment below Glen Canyon Dam.

\section{ACKNOWLEDGEMENTS}

This article was greatly improved by comments and suggestions from B.E. Ralston, L.G. Coggins, Jr., C.S. Magirl, S.A. Wright, and T.S. Melis. We are indebted to W.S. Vernieu and T.M. Gushue for providing graphical data. D.L. Polly provided valuable research assistance. This work was financially supported by the Glen Canyon Dam Adaptive Management Program and was conducted with permits from Grand Canyon National Park, U.S. Fish and Wildlife Service, and Arizona Game and Fish Department. The use of product names does not imply endorsement by the U.S. Government. Our analysis and conclusions were greatly advanced by the work of our esteemed colleague J.H. Petersen (deceased).

\section{REFERENCES}

[1] Xenopoulos MA, Lodge DM, Alcamo J, Marker M, Schulze K, VanVuuren DP. Scenarios of freshwater fish extinctions from climate change and water withdrawal. Glob Change Biol 2005; 11: $1557-64$.

[2] Xenopoulos MA, Lodge DM. Going with the flow: using speciesdischarge relationships to forecast losses in fish biodiversity. Ecology 2006; 87:1907-14.

[3] Eaton JG, Scheller RM. Effects of climate warming on fish thermal habitat in streams of the United States. Limnol Ocean 1996; 41: 1109-15

[4] Jackson DA, Mandrak NE. In: McGinn NA, Ed. Changing fish biodiversity: Predicting the loss of cyprinid biodiversity due to global climate change. American Fisheries Society Symposium 32. Bethesda, Maryland, American Fisheries Society 2002; pp. 89-98.
[5] Chu C, Mandrak NE, Minns CK. Potential impacts of climate change on the distributions of several common and rare freshwater fishes in Canada. Divers Distrib 2005; 11: 299-310.

[6] Rahel FJ, Olden JD. Assessing the effects of climate change on aquatic invasive species. Conserv Biol 2008; 22: 521-33.

[7] Carpenter SR, Fisher SG, Grimm NB, Kitchell JF. Global change and freshwater ecosystems. Ann Rev Ecol Syst 1992; 23: 119-39.

[8] Daufresne M, Boët P. Climate change impacts on structure and diversity of fish communities in rivers. Glob Change Biol 2007; 13: 2467-78.

[9] Rahel FJ, Bierwagen B, Taniguchi Y. Managing aquatic species of conservation concern in the face of climate change and invasive species. Conserv Biol 2008; 22: 551-61.

[10] Douglas ME, Marsh PC. Population estimate/population movements of Gila cypha, an endangered cyprinid fish in the Grand Canyon region of Arizona. Copeia 1996; 1: 15-28.

[11] Clarkson RW, Childs MR. Temperature effects of hypolimnialrelease dams on early life states of Colorado River basin big-river fishes. Copeia 2000; 2: 402-12.

[12] Ryan T. Bureau of Reclamation, Salt Lake City, Utah. 2008; [personal communication].

[13] Voichick, N, Wright SA. Water-temperature data for the Colorado River and tributaries between Glen Canyon Dam and Spencer Canyon, northern Arizona, 1988-2005. U.S. Geological Survey Data Series 2007; No. 251.

[14] Yard MD, Bennett GE, Mietz SN, et al. Influence of topographic complexity on solar insolation estimates for the Colorado River, Grand Canyon, Arizona. Ecol Model 2005; 183: 157-72.

[15] Huntoon PW. Fault controlled ground-water circulation under the Colorado River, Marble Canyon, Arizona. Ground Water 1981; 19: 20-7.

[16] USFWS (U.S. Fish and Wildlife Service). Humpback chub (Gila cypha) Recovery Goals: amendment and supplementation to the humpback chub Recovery Plan. Denver, Colorado, U.S. Fish and Wildlife Service, Mountain-Prairie Region (6), 2002.

[17] Valdez RA, Ryel RJ. Life history and ecology of the humpback chub (Gila cypha) in the Colorado River, Arizona. 1995; Final Report, Contract No. 0-CS-40-09110, Salt Lake City, UT.

[18] Coggins LG. Abundance trends and status of the Little Colorado River population of humpback chub; an update considering 19892006 data. U.S. Geological Survey Open-File Report No. 1402, 2007.

[19] Coggins LG Jr, Pine WE III, Walters CJ, VanHaverbeke DR, Ward D, Johnstone HC. Abundance trends and status of the Little Colorado River population of humpback chub. N Am J Fish Manage 2006; 26: 76-88.

[20] Coggins LG Jr, Walters CJ. Abundance trends and status of the Little Colorado River population of humpback chub; an update considering data from 1989-2008. U.S. Geological Survey OpenFile Report No. 1075, 2009.

[21] U.S. Department of the Interior, Bureau of Reclamation. Final Environmental Impact Statement on the Operation of Glen Canyon Dam. Salt Lake City, Utah, United States Department of the Interior, Bureau of Reclamation, Colorado River Region 1995.

[22] Gorman OT, Stone DM. Ecology of spawning humpback chub, Gila cypha, in the Little Colorado River near Grand Canyon, Arizona. Environ Biol Fish 1999; 55: 115-33.

[23] Kaeding LR, Zimmerman MA. Life history and ecology of the humpback chub in the Little Colorado and Colorado Rivers of the Grand Canyon. Trans Am Fish Soc 1983; 112: 577-94.

[24] Hamman RL. Spawning and culture of humpback chub. Prog Fish-Culturist 1982; 44: 213-16.

[25] Minckley CO. Observed growth and movement in individuals of the Little Colorado population of the humpback chub (Gila cypha). Proc Desert Fish Counc 1991; 22: 35-6.

[26] Paukert CP, Coggins LG Jr., Flaccus CE. Distribution and movement of humpback chub in the Colorado River, Grand Canyon, based on recaptures. Trans Am Fish Soc 2006; 135: 539-44.

[27] Valdez RA, Masslich WJ. Evidence of reproduction by humpback chub in a warm spring of the Colorado River in Grand Canyon, Arizona. SW Natural 1999; 44: 384-87.

[28] Minckley WL, Deacon JE, Eds. Battle Against Extinction. Tucson: University of Arizona Press 1991.

[29] Tyus HM, Saunders JF III. Nonnative fish control and endangered fish recovery: lessons from the Colorado River. Fisheries 2000; 25: 17-24. 
[30] Woodbury AM, Flowers S, Lindsay DW, et al. Ecological Studies of the Flora and Fauna in Glen Canyon, University of Utah Anthropological Papers 40 (Glen Canyon Series Number 7), University of Utah, Salt Lake City; 1959.

[31] Coggins LG Jr. Active adaptive management for native fish conservation in the Grand Canyon: Implementation and evaluation. Ph.D. dissertation. Gainesville, University of Florida: 2008.

[32] Petersen JH, Paukert CP. Development of a bioenergetics model for humpback chub and evaluation of water temperature changes in the Grand Canyon, Colorado River. Trans Am Fish Soc 2005; 134: 960-74.

[33] Diana JS. Biology and ecology of fishes. Carmel, Indiana: Biological Sciences Press, Cooper Publishing Group 1995.

[34] Jobling M. Temperature tolerance and the final preferendum rapid methods for the assessment of optimum growth temperatures. J Fish Biol 1981; 19: 439-55.

[35] Paukert CP, Petersen JH. Comparative growth and consumption potential of rainbow trout and humpback chub in the Colorado River, Grand Canyon, Arizona, under different temperature scenarios. Sout West Nat 2007; 52: 234-42.

[36] Topping DJ, Rubin DM, Schmidt JC, et al. Comparison of sediment-transport and bar-response results from the 1996 and 2004 controlled-flood experiments on the Colorado River in Grand Canyon. Proceedings of the $8^{\text {th }}$ Federal Inter-Agency Sedimentation Conference, Reno, Nevada, April 2-6, 2006.

[37] Bilotta GS, Brazier RE. Understanding the influence of suspended solids on water quality and aquatic biota. Water Res 2008; 42: 2849-61.

[38] Magirl CS. Bedrock-controlled fluvial geomorphology and the hydraulics of rapids on the Colorado River. Ph.D. dissertation. Tucson University of Arizona: 2006.

[39] Hanks TC, Webb RH. Effects of tributary debris on the longitudinal profile of the Colorado River in Grand Canyon. J Geophys Res 2006; 111: F02020.

[40] Rubin DM, Schmidt JC, Moore JN. Origin, structure, and evolution of a reattachment bar, Colorado River, Grand Canyon, Arizona. J Sediment Petrol 1990; 60: 982-91.

[41] Wright SA, Schmidt JC, Melis TS, Topping DJ, Rubin DM. Is there enough sand? Evaluating the fate of Grand Canyon sandbars. GSA Today 2008; 18: 4-10.
[42] Hanson, PC, Johnson TB, Schindler DE, Kitchell JF. Bioenergetics model 3.0 for Windows. University of Wisconsin, Sea Grant Institute, Technical Report WISCU-T-97-001, Madison 1997.

[43] Kitchell JF, Stewart DJ, Weininger D. Applications of a bioenergetics model to yellow perch (Perca flavescens) and walleye (Stizostedion vitreum vitreum). J Fish Res Board Can 1977; 34: 1922-35.

[44] Minckley CO. Observations on the biology of the humpback chub in the Colorado River Basin, 1908-1990. Ph.D. Dissertation, Northern Arizona University: Flagstaff; 1996.

[45] Stone DM. Ecology of humpback chub (Gila cypha) in the Little Colorado River, near Grand Canyon, Arizona. M.S. Thesis, Northern Arizona University: Flagstaff; 1999.

[46] Magirl CS, Webb RH, Griffiths P. Modeling water-surface elevations and virtual shorelines for the Colorado river in Grand Canyon, Arizona. U.S. Geological Survey Scientific Investigations Report No. 5075, 2008.

[47] Berry CR Jr., Pimentel R. Swimming performances of three rare Colorado River fishes. Trans Am Fish Soc 1985; 114: 397-402.

[48] Castro-Santos T. Optimal swim speeds for traversing velocity barriers: an analysis of volitional high-speed swimming behavior of migratory fishes. J Exp Biol 2005; 208: 421-32.

[49] Ward DL. Effects of marking techniques and handling on swimming ability of bonytail chub. J Arizona-Nevada Acad Sci 2003; 36: 34-6.

[50] Videler JJ, Wardle CS. Fish swimming stride by stride: speed limits and endurance. Rev Biol Fish 1991; 1: 23-40.

[51] Claireaux G, Couturier C, Groison AL. Effect of temperature on maximum swimming speed and cost of transport in juvenile European sea bass (Dicentrarcus labrax). J Exp Biol 2006; 209: 342028.

[52] Adams SR, Adams GL, Hoover JJ. Oral grasping: a distinctive behavior of cyprinids for maintaining station in flowing water. Copeia 2003; 4: 851-57.

[53] Seager R, Ting M, Held I, et al. Model projections of an imminent transition to a more arid climate in southwestern North America. Science 2007; 316: 1181-4.

Received: October 07, 2009

Revised: January 211, 2010

Accepted: January 25, 2010

(C) Andersen et al.; Licensee Bentham Open.

This is an open access article licensed under the terms of the Creative Commons Attribution Non-Commercial License (http: //creativecommons.org/licenses/by-nc/3.0/) which permits unrestricted, non-commercial use, distribution and reproduction in any medium, provided the work is properly cited. 